\title{
Studies on Genetic Variability for Yield and Quality Traits in Finger Millet (Eluesine coracana L. Gaertn)
}

\author{
Anusha Udamala $^{1^{*}}$, B. Vijayalakshmi ${ }^{1}$, N. Anuradha ${ }^{2}$, T. S. S. K. Patro ${ }^{2}$ and V. Sekhar ${ }^{3}$ \\ ${ }^{1}$ Department of Genetics and Plant Breeding, Agriculture college, Bapatla, \\ Guntur-522001, A.P, India \\ ${ }^{2}$ Agricultural Research Station, Vizianagaram, 535 001, A.P., India \\ ${ }^{3}$ Department of Statistics, College of Horticulture, Dr. Y.S.R. Horticultural University, West \\ Godavari, A.P - 534101 \\ *Corresponding author
}

\section{A B S T R A C T}

Keywords

Finger millet,

Variability,

Heritability,

Genetic advance,

Yield and Quality

attributing traits

Article Info

Accepted:

07 August 2020

Available Online:

10 September 2020
Thirty blast resistant lines of finger millet were evaluated in a field study to assess the magnitude of genetic variability, heritability and genetic advance for yield and quality attributing traits. The analysis of variance revealed that there were significant differences among the entries for all the traits studied. The genetic parameters revealed that moderate to high variability coupled with high heritability and high genetic advance as per cent of mean for agronomic traits viz., days to $50 \%$ flowering, days to maturity, fingers per ear head, finger width, test weight, productive tillers per plant and quality traits like calcium content, iron content, zinc content, protein content and anti-oxidant activity suggesting the predominance of additive type of gene action in controlling these traits and improvement of these characters is possible through simple selection.

\section{Introduction}

Eleusine coracana (L). Gaertnis one of the important sustenance millets grown extensively in various regions of Africa and South Asia.It is widely adapted to grow even at higher altitude regions where other crops fail to grow hence it serves as a food security crop having high nutritive and culture value. It is also known to be one of the most efficient utilizer of nitrogen (Gupta et al., 2014). Globally, it stands fourth in production among millets after sorghum, bajra and foxtail millet (Upadhyaya et al., 2017). In India the overall cultivated area under this crop is 10.16 lakh hectares with 13.85 lakh tonnes production and $1363 \mathrm{~kg} \mathrm{ha}^{-1}$ productivity (www.indiastat.com 2016-17), whereas in Andhra Pradesh, it is grown in 0.35 lakh hectares with 0.44 lakh tonnes production and 
productivity of $1277 \mathrm{Kg} \mathrm{ha}{ }^{-1}$ (Agricultural statistics at a glance 2017-18). Finger millet is considered to be one of the nutritious millet as grains are nutritionally superior by providing fair amount of proteins, minerals and vitamins in abundance to the consumers. Finger millet contains 8-10 times more calcium content than that of rice or wheat. The carbohydrate present in ragi has a unique property of slower digestibility and therefore considered as food for long subsistence. It is highly valued as a substitute food in the times of drought. Demand for millets is increasing day by day and keeping in view of the future demand, there is a continues need to evolve new varieties which should exceed the yield of existing varieties in both yield and quality.

The crop improvement depends mainly on basic information on the existence of genetic variability and diversity in population and the relationship between different traits. Presence of high variability offers much scope for its improvement (Poehlman, 1987). Success of hybridization and selection of desirable segregants can be possible by choosing of diverse parents with maximum magnitude of genetic variability for different traits. Estimation of genetic variability alone does not provide clear cut indication of possible advancement that can be achieved through selection and it should be coupled with heritability and genetic advance (Venkatesan et al., 2004). Heritability and genetic advance are important selection parameters when considered together help the breeders in determining the traits having better corresponding between phenotypes and genotypes and are expected to give better response to selection (Binse et al., 2006). Hence, an attempt was made to determine the performance of 30 finger millet genotypes to assess the variability, phenotypic coefficient of variation (PCV), genotypic coefficient of variation (GCV), heritability and genetic advance among sixteen traits which would contribute to formulation of suitable selection indices for improvement.

\section{Materials and Methods}

The present investigation was carried out at Agriculture Research Station, Vizianagaram, Andhra Pradesh, located at an altitude of $63 \mathrm{~m}$ above mean sea level, latitude of $18.12{ }^{0} \mathrm{~N}$ and longitude of $83.40^{\circ} \mathrm{E}$ with sandy loamy soil having $\mathrm{pH}$ 7.3.The experimental material comprised of 30 genotypes consisting of 11 varieties released i.e. five from Agricultural Research Station (ARS), Vizianagaram, one each from Agricultural Research Station, Peddapuram and Agricultural Research Station, Perumallapalli and two from Bangalore and two from Almora, Uttarakhand apart from 11 advanced breeding lines and eight exotic germplasm lines collected from ICRISAT, Hyderabad (Table 1). The genotypes were evaluated in a Randomized Block Design with three replications during kharif, 2019. Each plot consisted of four rows of 4 meters length with a spacing of $30 \times 10$ $\mathrm{cm}$.

All the recommended agronomic packages of practices were followed during the entire crop period. In each replication, five random plants were chosen and observations were recorded on eleven yield viz., days to $50 \%$ flowering, days to maturity, plant height, number of productive tillers per plant, number of fingers per ear, finger length, finger width, test weight, harvesting index, fodder yield and grain yield and five quality traits viz., protein content, calcium content, iron content, zinc content and anti-oxidant activity.

The mean values were subjected to statistical analysis and the genetic parameters such as phenotypic coefficient of variation (PCV), genotypic coefficient of variation (GCV), heritability and Genetic advance as per cent of mean were established as per Burton et al., 
(1952) and Johnson et al., (1955) to assess the genetic variability of yield and quality traits.

\section{Results and Discussion}

Analysis of variance revealed highly significant differences among genotypes for the characters studied indicating presence of sufficient amount of variability in the studied material (Table 1). Thus, there is ample scope for selection of different quantitative characters for finger millet improvement. The mean, range, variability, heritability and genetic advance as per cent mean for sixteen traits were presented in Table 2. The range varied for calcium content $228.3 \mathrm{mg} / 100 \mathrm{~g}$ (VR 1101) to $626.7 \mathrm{mg} / 100 \mathrm{~g}$ (VL 352) with the mean value of $408.05 \mathrm{mg} / 100 \mathrm{~g}$, plant height varied from $89.5 \mathrm{~cm}$ (EG 24) to 120.1 $\mathrm{cm}$ (VR 1179) with the mean value of 110.55 $\mathrm{cm}$ and days to 50 percent flowering ranged from 50 days (VR 1125) to 83 days (EG 31) with a mean value of 69 days. The genotypic coefficient of variation for all the characters studied were lesser than phenotypic coefficient of variation indicate modifying effect of the environment in association with the characters at genotypic level. High PCV coupled with high GCV and was observed for high GCV for characters zinc content (36.52 and 36.02), iron content (24.56 and 22.87), calcium content (23.40 and 22.97) and protein content (22.21 and 20.97). Similar findings are in conformity with Banu et al., (2017) and Vaibhav Sharma (2018) for iron content. Padmaja (2006) and Sarala (2007) for calcium content and Maloo et al., (1998) for protein content. High PCV coupled with moderate GCV was recorded for the productive tillers per plant (21.79 and 19.79).

These findings are earlier reported by Jyothsna et al., (2016), Anuradha et al., (2017).When coefficient of variation is higher, the population has greater variability and scope for improvement of high yielding genotypes with diverse genotypes. Moderate
PCV and GCV was recorded for test weight (17.98 and 17.08), days to $50 \%$ flowering (16.28 and 16.15), grain yield per plot (16.28 and 13.47), anti-oxidant activity (15.28 and 12.67) fingers per ear head (15.14 and 14.36), finger width (14.09 and 13.19) and days to maturity (11.68 and 11.44) was observed. These findings are in conformity with Keerthana et al., (2019) for days to $50 \%$ flowering, grain yield per plot and fingers per ear head. While moderate PCV with low GCV for harvesting index (11.97 and 9.94) and finger length (11.43 and 8.37). Low PCV and GCV was exhibited for plant height (6.08 and 3.85). Indicating narrow range of variability among the tested genotypes. Similar results were reported by Devaliya et al., (2018) for plant height.

Heritability which is the heritable portion of phenotypic variance is a good index of transmission of characters from parents to offspring (Falconer, 1981). Assessment of heritability helps to get an idea to know about how intensity of the character under genetic control and has a close bearing on response to selection. Heritability estimates along with the genetic advance mean are more useful in predicting gain under selection than heritability estimate alone.

High broad sense heritability with high genetic advance as percent of mean was recorded for traits viz., days to $50 \%$ flowering (98.00 and 33.01), zinc content (97.00 and 73.19), days to maturity (96.00 and 23.01), calcium content (96.00 and 46.43), fingers per ear head (90.00 and 28.08), test weight (90.00 and 33.43),protein content (89.00 and 40.79), finger width (88.00 and 25.41), iron content (87.00 and 43.87), and anti-oxidant activity (69.00 and 21.63) and grain yield per plot (68.00 and 22.95) indicating that these traits were less influenced by environment and governs by additive gene action which may be exploited through simple selection procedures. 
Table.1 Analysis of variance for yield and yield components and quality traits among 30 genotypes of Finger millet (Eluesine coracana L. Gaertn)

\begin{tabular}{|c|c|c|c|}
\hline Source & Replications & Treatments & Error \\
\hline Degree of freedom & 2 & 29 & 58 \\
\hline \multicolumn{4}{|c|}{ Mean Sum of Squares } \\
\hline Days to $50 \%$ flowering & 0.90 & $375.87 * *$ & 5.80 \\
\hline Plant height $(\mathbf{c m})$ & 35.97 & $135.71 * *$ & 81.35 \\
\hline Finger length & 0.49 & $1.41 * *$ & 0.65 \\
\hline Finger width & 0.01 & $0.03 * *$ & 0.00 \\
\hline No.of productive tillers/plant & 0.29 & $1.22 * *$ & 0.21 \\
\hline Days to maturity & 8.14 & $394.50 * *$ & 15.91 \\
\hline Fingers per ear head & 0.45 & $4.05 * *$ & 0.40 \\
\hline Grain yield/plot & 6.69 & $60.94 * *$ & 19.23 \\
\hline Fodder yield & 42.58 & $217.25 * *$ & 58.95 \\
\hline Harvesting index & 0.00 & 0.00 & 0.00 \\
\hline Test weight & 0.00 & $0.67 * *$ & 0.06 \\
\hline Calcium content & 1180.28 & $27353.50 *$ & 1008.15 \\
\hline Iron content & 0.12 & $1.58 * *$ & 0.21 \\
\hline Zinc content & 0.01 & $0.90 * *$ & 0.02 \\
\hline Protein content & 0.28 & $150.31 * *$ & 32.69 \\
\hline Anti-oxidant activity & 99.60 & $440.01 * *$ & 137.59 \\
\hline
\end{tabular}

(**significance at 1 percent level)

Table.2 Mean, Variability, Heritability and Genetic advance as per cent of mean for yield and yield attributing and quality traits of Finger millet (Eluesine coracana L. Gaertn)

\begin{tabular}{|c|c|c|c|c|c|}
\hline \multirow{2}{*}{ Character } & \multirow{2}{*}{ Mean } & \multicolumn{2}{|c|}{$\begin{array}{c}\text { Coefficient of } \\
\text { variation }\end{array}$} & \multirow{2}{*}{$\begin{array}{c}\text { Heritability } \\
\text { (\%) (broad } \\
\text { sense) }\end{array}$} & \multirow{2}{*}{$\begin{array}{c}\text { Genetic advance } \\
\text { as percent of mean } \\
(5 \% \text { level })\end{array}$} \\
\hline & & PCV\% & GCV\% & & \\
\hline $\begin{array}{l}\text { Days to } 50 \% \\
\text { Flowering (days) }\end{array}$ & 68.77 & 16.28 & 16.15 & 98.00 & 33.01 \\
\hline Plant height (cm) & 110.55 & 6.08 & 3.85 & 40.00 & 5.02 \\
\hline Finger length $(\mathrm{cm})$ & 6.00 & 11.43 & 8.37 & 54.00 & 12.62 \\
\hline Finger width (cm) & 0.76 & 14.09 & 13.19 & 88.00 & 25.41 \\
\hline Productive tillers per plant & 2.92 & 21.79 & 19.79 & 82.00 & 1.08 \\
\hline Days to maturity (days) & 98.19 & 11.68 & 11.44 & 96.00 & 23.09 \\
\hline Fingers per ear head & 7.67 & 15.14 & 14.36 & 90.00 & 28.08 \\
\hline Grain yield/plot (g) & 27.99 & 16.28 & 13.47 & 68.00 & 22.95 \\
\hline Fodder yield (g) & 67.59 & 12.59 & 10.75 & 73.00 & 18.90 \\
\hline Harvesting index (\%) & 0.28 & 11.97 & 9.94 & 69.00 & 16.99 \\
\hline Test weight (g) & 2.62 & 17.98 & 17.08 & 90.00 & 33.43 \\
\hline Calcium content $(\mathrm{mg} / \mathbf{1 0 0 g})$ & 408.05 & 23.40 & 22.97 & 96.00 & 46.43 \\
\hline Iron content (mg/100g) & 2.96 & 24.56 & 22.87 & 87.00 & 43.87 \\
\hline Zinc content (mg/100g) & 1.50 & 36.52 & 36.02 & 97.00 & 73.19 \\
\hline Protein content (per cent) & 5.92 & 22.21 & 20.97 & 89.00 & 40.79 \\
\hline Anti-oxidant activity (mg/100g) & 79.26 & 15.28 & 12.67 & 69.00 & 21.63 \\
\hline
\end{tabular}

$\mathrm{PCV}=$ Phenotypic coefficient of variation GCV $=$ Genotypic coefficient of variation 
Table.3 Mean performance of genotypes studied for grain yield, yield attributes and quality traits in finger millet

\begin{tabular}{|c|c|c|c|c|c|c|c|c|c|c|c|c|c|c|c|c|c|}
\hline $\begin{array}{c}\text { S. } \\
\text { No. }\end{array}$ & Genotype & $\begin{array}{c}\text { Days to } \\
50 \% \\
\text { floweri } \\
\text { ng }\end{array}$ & $\begin{array}{c}\text { Plant } \\
\text { height } \\
(\mathbf{c m})\end{array}$ & $\begin{array}{c}\text { Finger } \\
\text { length } \\
(\mathrm{cm})\end{array}$ & $\begin{array}{c}\text { Finger } \\
\text { width } \\
\text { (cm) }\end{array}$ & $\begin{array}{l}\text { No. of } \\
\text { produ } \\
\text { ctive } \\
\text { tillers } \\
\text { per } \\
\text { plant }\end{array}$ & $\begin{array}{l}\text { Days } \\
\text { to } \\
\text { matu } \\
\text { rity }\end{array}$ & $\begin{array}{l}\text { No. of } \\
\text { finger } \\
\text { s per } \\
\text { ear } \\
\text { head }\end{array}$ & $\begin{array}{l}\text { Grain } \\
\text { yield } \\
\text { per } \\
\text { plot } \\
\text { plot }\end{array}$ & $\begin{array}{c}\text { Fodder } \\
\text { yield } \\
\text { per } \\
\text { plot }\end{array}$ & $\begin{array}{l}\text { Harves } \\
t \text { index }\end{array}$ & $\begin{array}{c}\text { Test } \\
\text { weight } \\
\text { (g) }\end{array}$ & $\begin{array}{c}\text { Calciu } \\
\text { m } \\
\text { content } \\
\text { (mg/10 } \\
\mathbf{0 g})\end{array}$ & $\begin{array}{c}\text { Iron } \\
\text { content } \\
\text { (mg/10 } \\
\text { 0g) }\end{array}$ & $\begin{array}{c}\text { Zinc } \\
\text { content } \\
(\mathrm{mg} / 10 \\
\mathbf{0 g})\end{array}$ & $\begin{array}{c}\text { Protein } \\
\text { content } \\
(\%)\end{array}$ & $\begin{array}{c}\text { Anti- } \\
\text { oxidant } \\
\text { activity } \\
\text { (mg/100 } \\
\text { g) }\end{array}$ \\
\hline 1 & $\begin{array}{l}\text { Sri } \\
\text { Chaitanya }\end{array}$ & 78 & 114.0 & 5.7 & 0.9 & 2.8 & 106.3 & 7.3 & 29.8 & 70.3 & 0.3 & 3.2 & 423.3 & 3.2 & 1.5 & 7.3 & 99.7 \\
\hline 2 & Bharathi & 80.7 & 113.9 & 5.9 & 0.9 & 3.1 & 110.3 & 7.3 & 28.1 & 67.5 & 0.3 & 3.4 & 405.0 & 2.9 & 1.5 & 7.3 & 78.6 \\
\hline 3 & $\begin{array}{l}\text { Champavat } \\
\text { hi }\end{array}$ & 50.7 & 103.3 & 5.3 & 0.6 & 2.9 & 79.0 & 6.9 & 21.7 & 53.5 & 0.3 & 2.8 & 366.7 & 2.4 & 1.6 & 5.8 & 91.0 \\
\hline 4 & Vegavathi & 75.7 & 115.1 & 6.4 & 0.9 & 3.1 & 105.0 & 8.5 & 31.9 & 78.4 & 0.3 & 3.0 & 318.3 & 4.0 & 1.1 & 3.3 & 83.7 \\
\hline 5 & VR 1101 & 64 & 116.4 & 5.9 & 0.8 & 3.8 & 93.0 & 8.6 & 34.8 & 74.7 & 0.3 & 2.6 & 228.3 & 2.2 & 1.2 & 6.2 & 92.0 \\
\hline 6 & VR 1110 & 76.3 & 114.8 & 6.2 & 0.8 & 3.5 & 105.3 & 6.9 & 33.8 & 72.4 & 0.3 & 2.8 & 458.3 & 2.2 & 1.6 & 7.5 & 81.4 \\
\hline 7 & VR 1151 & 61.3 & 114.0 & 5.4 & 0.8 & 3.1 & 92.3 & 8.5 & 32.1 & 69.1 & 0.3 & 2.6 & 430.0 & 2.6 & 1.6 & 5.9 & 98.7 \\
\hline 8 & VR 1131 & 65.3 & 110.4 & 5.9 & 0.6 & 3.1 & 94.0 & 9.1 & 31.8 & 51.5 & 0.4 & 2.8 & 616.7 & 4.2 & 1.1 & 6.2 & 79.9 \\
\hline 9 & VR 1125 & 50.3 & 110.0 & 6.2 & 0.8 & 3.4 & 79.3 & 8.6 & 31.6 & 72.7 & 0.3 & 2.6 & 471.7 & 3.0 & 1.3 & 5.3 & 83.3 \\
\hline 10 & VR 1112 & 81.0 & 117.1 & 6.1 & 0.8 & 4.4 & 110.0 & 7.2 & 35.3 & 80.0 & 0.3 & 3.1 & 446.7 & 2.0 & 1.2 & 7.2 & 75.6 \\
\hline 11 & VR 1117 & 55.0 & 107.4 & 5.9 & 0.9 & 2.7 & 83.7 & 8.8 & 29.0 & 61.4 & 0.3 & 2.7 & 438.3 & 4.0 & 0.9 & 5.1 & 86.7 \\
\hline 12 & VL 352 & 52.7 & 108.3 & 6.7 & 0.7 & 2.1 & 83.3 & 8.3 & 28.5 & 67.8 & 0.3 & 3.0 & 626.7 & 1.9 & 1.5 & 6.3 & 79.6 \\
\hline 13 & GPU 67 & 80.0 & 111.3 & 6.4 & 0.9 & 3.2 & 110.0 & 9.3 & 29.8 & 75.7 & 0.3 & 3.2 & 318.3 & 3.8 & 1.0 & 4.8 & 73.1 \\
\hline 14 & PR 202 & 78.7 & 109.1 & 5.5 & 0.8 & 3.1 & 111.0 & 8.1 & 30.4 & 71.3 & 0.3 & 3.2 & 256.7 & 2.2 & 1.2 & 6.7 & 75.9 \\
\hline 15 & Vakula & 58.3 & 108.4 & 6.3 & 0.9 & 2.4 & 86.7 & 8.9 & 26.3 & 60.3 & 0.3 & 2.9 & 493.3 & 2.2 & 1.4 & 5.5 & 81.6 \\
\hline 16 & EG 4 & 59.7 & 112.8 & 6.4 & 0.8 & 2.5 & 89.3 & 7.6 & 23.1 & 65.9 & 0.3 & 2.2 & 418.3 & 3.2 & 1.4 & 4.9 & 69.2 \\
\hline 17 & EG 16 & 62.7 & 110.3 & 5.5 & 0.9 & 2.3 & 92.0 & 7.6 & 29.2 & 76.4 & 0.3 & 2.3 & 403.3 & 3.6 & 1.2 & 5.7 & 72.8 \\
\hline 18 & EG 17 & 81.7 & 109.5 & 5.8 & 0.5 & 1.9 & 111.0 & 7.4 & 27.9 & 56.8 & 0.3 & 2.7 & 483.3 & 3.3 & 1.5 & 5.2 & 98.6 \\
\hline 19 & EG 18 & 80.3 & 114.1 & 7.9 & 0.7 & 3.9 & 110.7 & 7.3 & 23.5 & 74.5 & 0.2 & 2.0 & 545.0 & 2.5 & 3.5 & 6.5 & 54.4 \\
\hline 20 & EG 21 & 59.7 & 104.3 & 6.4 & 0.8 & 1.7 & 88.7 & 5.8 & 24.0 & 64.0 & 0.3 & 2.1 & 391.7 & 2.7 & 1.4 & 7.4 & 97.2 \\
\hline 21 & EG 24 & 78.3 & 89.5 & 4.1 & 0.6 & 3.5 & 106.7 & 6.4 & 29.9 & 69.4 & 0.3 & 2.0 & 321.7 & 3.1 & 1.3 & 5.7 & 86.7 \\
\hline 22 & EG 31 & 82.7 & 118.6 & 7.0 & 0.7 & 3.6 & 111.7 & 7.2 & 25.7 & 64.6 & 0.3 & 2.2 & 365.0 & 2.6 & 1.3 & 5.5 & 81.1 \\
\hline 23 & VR 1179 & 60.0 & 120.1 & 5.6 & 0.7 & 1.8 & 89.7 & 4.8 & 13.5 & 54.5 & 0.2 & 2.3 & 426.7 & 2.9 & 1.5 & 9.2 & 71.8 \\
\hline 24 & VR 1174 & 77.0 & 90.7 & 6.1 & 0.6 & 2.3 & 107.7 & 5.2 & 23.1 & 73.4 & 0.2 & 2.1 & 398.3 & 4.2 & 2.8 & 5.5 & 76.2 \\
\hline 25 & EG 48 & 76.3 & 109.9 & 5.5 & 0.8 & 2.9 & 108.7 & 7.8 & 24.9 & 60.3 & 0.3 & 2.1 & 336.7 & 2.1 & 1.2 & 6.2 & 67.0 \\
\hline 26 & VR 1171 & 62.7 & 114.4 & 5.5 & 0.8 & 2.8 & 91.0 & 7.7 & 23.4 & 63.6 & 0.3 & 2.1 & 268.3 & 3.2 & 2.5 & 7.0 & 62.1 \\
\hline
\end{tabular}




\begin{tabular}{|c|c|c|c|c|c|c|c|c|c|c|c|c|c|c|c|c|c|}
\hline $\begin{array}{l}\dot{z} \\
\dot{n}\end{array}$ & 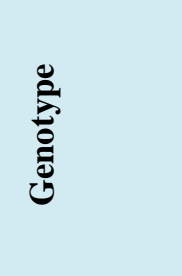 & 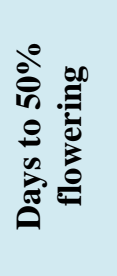 & 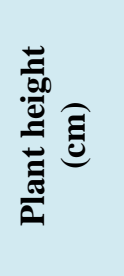 & 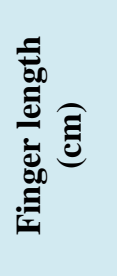 & 昰 & 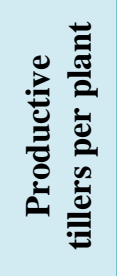 & 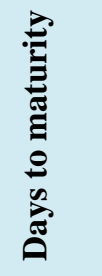 & 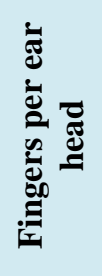 & 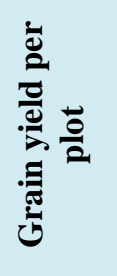 & 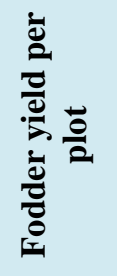 & 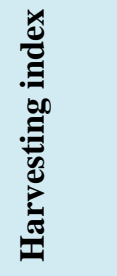 & 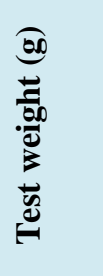 & 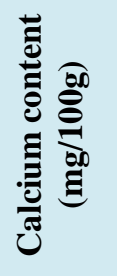 & 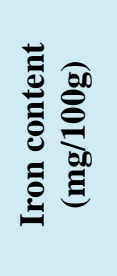 & 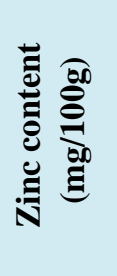 & 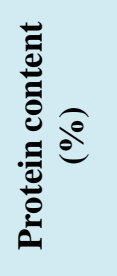 & 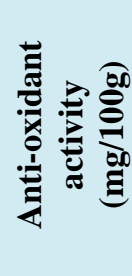 \\
\hline 27 & VR1165 & 80.0 & 114.1 & 6.7 & 0.8 & 3.4 & 109.3 & 7.0 & 25.8 & 86.4 & 0.2 & 2.2 & 273.3 & 2.2 & 1.5 & 2.6 & 73.3 \\
\hline 28 & VR1163 & 60.0 & 110.8 & 5.6 & 0.7 & 3.3 & 89.0 & 7.7 & 26.8 & 73.4 & 0.3 & 1.9 & 391.7 & 2.6 & 1.2 & 4.4 & 65.7 \\
\hline 29 & GPU 45 & 80.7 & 113.1 & 5.2 & 0.7 & 2.9 & 109.0 & 8.7 & 28.1 & 61.4 & 0.3 & 3.4 & 453.3 & 4.1 & 1.6 & 6.6 & 53.2 \\
\hline \multirow[t]{6}{*}{30} & VL 376 & 53.7 & 110.8 & 6.7 & 0.7 & 2.4 & 82.0 & 9.7 & 26.9 & 56.3 & 0.3 & 3.2 & 466.7 & 4.0 & 1.3 & 4.5 & 87.6 \\
\hline & Mean & 68.77 & 110.55 & 6.00 & 0.76 & 2.93 & 98.19 & 7.67 & 27.69 & 67.59 & 0.29 & 2.62 & 408.06 & 2.96 & 1.50 & 5.92 & 79.26 \\
\hline & Maximum & 82.7 & 120.1 & 7.9 & 0.9 & 4.4 & 111.7 & 9.7 & 35.3 & 86.4 & 0.4 & 3.4 & 626.7 & 4.2 & 3.5 & 9.2 & 79.26 \\
\hline & Minimum & 50.3 & 89.5 & 4.1 & 0.5 & 1.7 & 79.0 & 4.8 & 13.5 & 51.5 & 0.2 & 1.9 & 228.3 & 1.9 & 0.9 & 2.6 & 53.2 \\
\hline & C.V. & 3.50 & 8.16 & 13.48 & 8.61 & 15.82 & 4.06 & 8.28 & 15.84 & 11.36 & 11.57 & 9.72 & 7.78 & 15.50 & 10.44 & 12.69 & 14.80 \\
\hline & C.D. $5 \%$ & 3.93 & 14.74 & 1.32 & 0.11 & 0.76 & 6.52 & 1.04 & 7.17 & 12.55 & 0.05 & 0.42 & 51.89 & 0.75 & 0.26 & 1.23 & 19.17 \\
\hline
\end{tabular}


These results were in accordance with Shinde et al., (2014), Jyothsna et al., (2016) for days to $50 \%$ flowering and days to maturity. Prashantha et al., (2018) and Keerthana et al., (2019) for fingers per ear head and grain yield per plot. High heritability with low genetic advance as percent of mean was observed for productive tillers per plant (82.00 and 1.08). These findings are in conformity with Bharathi et al., (2013). While moderate heritability with moderate genetic advance was observed for finger length (54.00 and 12.62). These findings are in uniformity with Patil and Mane (2013) and Reddy et al., (2013). Moderate heritability with low genetic advance was exhibited by plant height $(40.00$ and 5.02). Similar results are reported by Sao et al., (2016). However, it is not necessary that a character showing high heritability will also exhibit high genetic advance (Johnson et al., 1955). Such conditions were most likely caused by additive gene action, thereby, reflecting the efficiency of selection for the improvement of these traits. According to Panse (1957), if the heritability is mainly owing to non-additive gene effect, the expected genetic advance would be low and if there is additive gene effect, a high genetic advance may be expected.

The present experimental study revealed that there exists an adequate amount of variability in the genotypes studied. The estimates of phenotypic coefficients of variation was slightly higher than the estimates of genotypic coefficients of variation for all traits under study implying that besides genetic factors some environmental factors are having their role in expression of characters. The genetic parameters revealed that moderate to high GCV, PCV coupled with high heritability and high genetic advance as percent of mean were observed for days to $50 \%$ flowering, days to maturity, fingers per ear head, finger width, test weight, productive tillers per plant, calcium content, iron content, zinc content, protein content and anti-oxidant activity. These results indicate the operation of additive gene action in the inheritance of these traits and improvement of these traits are possible through simple selection. In the present investigation, the genotype VL 376 recorded maximum mean performance for more number of characters i.e. days to $50 \%$ flowering, days to maturity, fingers per ear head, test weight, iron content and antioxidant activity which also exhibiting high PCV to moderate GCV along with high heritability with high genetic advance. Further the genotypes namely, Vegavathi, VR1131, VR 1117, VL 352 and VL 376 are identified as promising varieties for utilization in hybridization programme aimed at developing varieties with high yield and quality traits.

\section{References}

Agricultural Statistics at a Glance 201718.Directorate of Economics and Statistics https://desap.cgg.gov.in

Anuradha, N., Patro, T.S.S.K., Divya, M., Sandhya, Y.R and Triveni, U., 2017. Genetic variability, heritability and association in advanced breeding lines of finger millet [Eluesine coracana (L.) Gaertn.]. International Journal of Chemical Studies. 5 (5): 1042-1044.

Banu, H., Gowda, J and Nanjareddy, Y.A. 2017. Identification of elite germplasm at multilocational for nutritional quality parameters in foxtail millet [Setaria italica (L.) Beauv.]. Green farming. 8 (5): 1189-1192.

Bharathi, A., Veerabadhiran, P., Gowda, C.L.L and Upadhaya, H.D., 2013. Genetic Variability and Correlation Analysis in Global Composite Collection of Finger Millet (Eleusine coracana (L.) Gaertn). Madras Agricultural Journal, 100.

Binse, R., Motiramani, N. K and Sarwgi. 2006. Association analysis and 
variability analysis in rice. Mysore Journal of Agricultural Sciences. 40 (3): 375-380.

Burton, G. W and De vane, E. H. 1952. Estimating heritability in tall Fescue (Festuca arundinacea) from replicated clonal material. Agronomy Joural. 45: 478- 481.

Devaliya, S.D., Singh, M., Intawala, C.G and Bhagora, R.N., 2018. Genetic Variability Studies in Finger Millet (Eleusine coracana (L.) Gaertn. International Journal of Pure and Applied Biosciences, 6 (1): 10071011.

Falconer, D.S. 1964. An Introduction of Quantitative Genetics-Second edition. Oliver and Boyd, Edinburgh. 312-324.

Gupta, S., Gupta, S. M., Gupta, A. K., Gaur, V. S and Kumar, A. (2014). Fluctuation of Dof1/Dof2 expression ratio under the influence of varying nitrogen and light conditions: Involvement in differential regulation of nitrogen metabolism in two genotypes of finger millet (Eleusine coracana L.). Gene. 546: 327-335.

*Hanson, C. H., Robinson, H.F and Comstock, R.E. 1956. Biometrical studies of yield in segregating populations of Korean Lespedeza. Agronomy Journal. 48 (6): 268-272.

Johnson, H. W., Robinson, H. F and Comstock, R. E. 1955. Estimates of genetic and environmental variability in soybean. Agronomy Journal. 47: 314318.

Jyothsna, S., Patro, T.S.S.K., Ashok, S., Rani, Y.S and Neeraja, B., 2016. Studies on genetic parameters, character association and path analysis of yield and its components in finger millet (Eluesine coracana L. Gaertn). International Journal of Theoretical and Applied Sciences, 8 (1): 25.
Keerthana, K., Chitra, S., Subramanian, A., Nithila, S and Elangovan, M. 2019. Studies on genetic variability in finger millet [Eleusine coracana (L.) Gaertn] genotypes under sodic conditions. Electronic Journal of Plant Breeding, 10 (2): 566-569.

Lule, D., Tesfaye, K., Fetene, M. and De Villiers, S., 2012. Inheritance and association of quantitative traits in finger millet (Eleusine coracana Subsp. Coracana) landraces collected from Eastern and South Eastern Africa. International Journal of Genetics, 2 (2): 12-21.

Maloo, S.R., Solanki, J.S and Sharma, S.P. 1998. Genotypic variability for quality traits in finger millet [Eleusine coracana (L.) Gaertn.]. International Journal of Sorghum and Millets. 39: 126-128.

Padmaja, G., Rao, C.P., Kumar, P.V.R and Rao, V.S. 2006. Classical and restriction selection indices in AICSMIP group of genotypes of finger millet [Eleusine coracana (L.) Gaertn.]. The Andhra Agricultural Journal. 53 (3): 61-65.

Panse, V. G and Sukhatme, P. V. 1967. Statistical Methods for Agricultural workers. Indian Council of Agricultural Research, New Delhi. 103-108.

Patil, A.S and Mane, V.A. 2013. Studies on the genetic variation of yield and contributing traits in finger millet [Eleusine coracana (L.) Gaertn]. Society for Scientific Development in Agriculture and Technology. 8: 526528.

Poehlman, J. M. 1987. Breeding Field Crops. 3rd edition. AVI Publishing Company, Inc. West Port, Pp: 71-77

Prashantha, B.N., Gowda T.H., Gangaprasad, S., Nataraju, S.P and Veeranna, H. K. 2018. Genetic variability studies for yield and yield contributing traits in 
finger millet [Eleusine coracana (L.) Gaertn] genotypes. Journal of Farm Sciences. 31 (5): 527-531

Sao, A., Kumar, P., Singh, P and Pradhan, A. 2016. Genetic analysis for yield and economic traits in finger millet (Eleusine coracana (L.) Garten.). Society for Scientific Development in Agriculture and Technology.11-15

Sarala, N. 2007. Phenotypic stability analysis in finger millet [Eleusine coracana $(\mathrm{L}$. Gaertn.]. M.Sc. (Ag.) Thesis, Acharya N. G Ranga Agricultural University, Hyderabad.

Shinde, S.R., Desai, S.V and Pawar, R.M., 2014. Genetic variability and character association in finger millet [Eleusine coracana (L.) Gaertn]. International Journal of Plant Sciences (Muzaffarnagar). 9 (1):13-16.

Ulaganathan, V and Nirmalakumari, A., 2014. Genetic variability and correlation studies for quantitative traits in finger millet [Eleusine Coracana (L.) Gaertn] germplasm. The Ecoscan. 6: 21-25.

Upadhyaya, H.D., Gowda, C.L.L and Reddy, V.G. 2007. Morphological diversity in finger millet germplasm introduced from Southern and Eastern Africa. Journal of SAT Agricultural Research. 3 (1): 1-3.

Vaibhav Sharma, 2018. Genetic Variability and Character Association in Restorer Lines of Pearl Millet [Pennisetum glaucum (L.) R. Br.]. M. Sc Thesis. Swami Keshwanand Rajasthan Agricultural University, Bikaner, Rajasthan, India.

Venkatesan, M., Veeramani N., Anbuselvam, Y and Ganesan, J. 2004. Correlation and path analysis in blackgram (Vigna mungo L.). Legume Research. 27: 197200. www.indiastat.com 2016-17.

\section{How to cite this article:}

Anusha Udamala, B. Vijayalakshmi, N. Anuradha, T. S. S. K. Patro and Sekhar, V. 2020. Studies on Genetic Variability for Yield and Quality Traits in Finger Millet (Eluesine coracana L. Gaertn). Int.J.Curr.Microbiol.App.Sci. 9 (09): 641-649. doi: https://doi.org/10.20546/ijcmas.2020.909.081 